\title{
Doctor of Education
}

National Cancer Institute

\section{Source}

National Cancer Institute. Doctor of Education. NCI Thesaurus. Code C71359.

A professional doctorate that prepares the student for academic, administrative or specialized positions in education. 